\title{
O “Bom Selvagem Ecológico” na Tela, nas Páginas e na Floresta: invenções contemporâneas da Amazônia
}

Shaula Maira Vicentini Sampaio ${ }^{1}$

Maria Lúcia Castagna Wortmann ${ }^{2}$

\section{RESUMO}

O “BOM SELVAGEM ECOLÓGICO” NA TELA, NAS PÁGINAS E NA FLORESTA: INVENÇÕES CONTEMPORÂNEAS DA AMAZÔNIA. Este artigo apresenta análises de textos publicados em jornais e revistas brasileiros, abordando alguns dos significados sobre a Amazônia que participam ativamente dos modos como essa região vem sendo inventada na contemporaneidade. Tais produtos midiáticos atuam como pedagogias culturais que ensinam as pessoas a pensarem a Floresta Amazônica e seus habitantes de determinadas formas: mais especificamente, enfocamos os enunciados que se referem à articulação entre este ambiente e as populações tradicionais que o habitam. Com esse propósito, as análises desenvolvidas centramse em analogias feitas entre o filme Avatar e a Amazônia, pois, no período em que o filme foi lançado, circularam na mídia impressa diversos debates acerca das semelhanças entre a realidade dos povos amazônicos e os aborígenes dessa obra de ficção. Essa narrativa fílmica se vale, de modo emblemático, dos discursos sobre o "bom selvagem ecológico", que muitas vezes se entrelaçam a discussões sobre as populações tradicionais. Algumas das lições que destacamos nas discussões tecidas neste artigo dizem respeito à instituição de modos mais sustentáveis de lidar com os recursos naturais e de tecer relações com a biodiversidade amazônica que seriam característicos a essas populações tradicionais.

Palavras-chave: Floresta Amazônica; populações tradicionais; educação ambiental.

\footnotetext{
1 É bacharel e licenciada em Ciências Biológicas pela Universidade Estadual de Campinas (1998). Fez o mestrado em Educação pela Universidade Federal do Rio Grande do Sul (2005), tendo pesquisado os discursos relacionados à constituição de identidades em Educação Ambiental a partir da perspectiva dos Estudos Culturais. É doutora em Educação pela Universidade Federal do Rio Grande do Sul. Atua como professora do curso de Ciências Biológicas da Universidade Federal Fluminense (UFF).

2 É professora da Universidade Luterana do Brasil e professora pesquisadora convidada da Universidade Federal do Rio Grande do Sul. Tem experiência na área de Educação, com ênfase em Estudos Culturais em Educação, atuando principalmente nos seguintes temas: estudos culturais em educação, estudos culturais, educação em ciência, pedagogias culturais e estudos culturais de ciência.

Ci. Huma. e Soc. em Rev. RJ, EDUR, vol. 35, n.2, jul / dez, p. 97-113, 2013
} 


\begin{abstract}
THE ECOLOGICALLY NOBLE SAVAGE ON SCREEN, ON PAPER AND IN THE WOODS: CONTEMPORARY INVENTIONS OF AMAZONIA. This article presents some analysis of texts published in Brazilian newspapers and magazines regarding some of the meanings of the Amazon that actively participate in the ways that this region has been invented in the contemporary world. These media products act as cultural pedagogies that teach people how to think about the Amazon rainforest and its inhabitants in certain ways: more specifically, we focus on the statements that refer to the relationship between this environment and the traditional people who inhabit it. For this purpose, the analyzes focused on analogies drawn between the film Avatar and the Amazon, for, in the period in which the film was released, several debates gained the pages of the written press, discussing the similarities between the reality of Amazonian people and the aborigines of this fiction work. The narrative of the film relies, in such an emblematic way, on the speeches on the Ecologically Noble Savage, which are often intertwined with discussions about traditional populations. Some of the lessons highlighted in the discussions woven in this article regard the establishment of more sustainable modes of dealing with natural resources and building better relationships with the Amazon biodiversity. Such features are shown in the film as characteristics which naturally belong to these traditional populations.
\end{abstract}

Key words: the Amazon rainforest; traditional populations; environmental education.

\title{
INTRODUÇÃO
}

Um espaço vazio que deve ser preenchido, ocupado. Um paraíso de natureza exuberante. Uma fonte de recursos que ainda não são suficientemente conhecidos. A prova vívida da grandiosidade da natureza. Um baú de riquezas que podem ser exploradas no futuro. Patrimônio da humanidade. Uma zona de fronteiras que devem ser protegidas em prol da soberania nacional. Um lugar atrasado que necessita de investimentos públicos. Área de controle internacional. Um território onde há muitos conflitos fundiários. Um lugar em que povos e natureza convivem pacificamente há milhares de anos. Uma região que necessita de um zoneamento e de um modelo de desenvolvimento específicos. Moradia de povos que estão desaparecendo e guardam conhecimentos imprescindíveis para o desenvolvimento sustentável. Manejo sustentável, sequestro de carbono, pesquisa científica, desmatamento, biotecnologia, biopirataria, conhecimentos tradicionais, extrativismo, terras indígenas, narcotráfico, florestania, monitoramento ambiental...

Esse amontoado de palavras, metáforas e expressões apontam para a impossibilidade de dar destaque a todas as questões, controvérsias e polêmicas que dizem respeito à Amazônia, bem como permitem entrever a diversidade de narrativas relacionadas a esse "território". De qualquer 
forma, cabe salientar que, de modo cada vez mais acentuado, diferentes olhares e interesses têm se voltado para a região amazônica. O alvo desses interesses é, no entanto, bastante variável, podendo dirigir-se à conservação da floresta, à valorização e ao reconhecimento das culturas das populações tradicionais, aos minérios que jazem sob o solo, ao potencial hídrico de seus rios, à defesa das fronteiras, às valiosas madeiras de lei que podem ser extraídas das matas, à defesa dos direitos indígenas, entre tantos outros.

Por outro lado, é preciso considerar que alguns dos múltiplos olhares para a Amazônia remontam a tempos passados, pois significados a ela atribuídos, em diferentes períodos históricos, foram configurando essa região de determinados modos e demarcando maneiras específicas de sobre ela pensar e de nela intervir a partir dos interesses vigentes nesses períodos. Algumas dessas marcas demonstraram ser bastante persistentes, visto que, ainda hoje, nos defrontamos com discursos que emergiram em épocas remotas imiscuídos nesse processo de inventar, "desinventar" e reinventar essa região. Portanto, é importante compreendermos os discursos sobre a floresta como construídos (ou inventados) histórica e culturalmente. Com isso, como esclarece Guimarães (2006), tornase possível desnaturalizar alguns significados que se "colam" à Amazônia, em função de terem sido tantas vezes enunciados e repetidos. Esses significados circulam em muitas instâncias e/ou artefatos culturais, tais como a literatura, o cinema, a escola, a televisão.

A noção de invenção, utilizada neste texto, busca precisamente afastar qualquer possibilidade de se naturalizar os significados que produzem variados modos de narrar, pensar e agir com relação à Floresta Amazônica. Tal como indica Albuquerque Junior (2007, p.21), estudar os processos de invenção de objetos ou sujeitos possibilita vê-los como fabricações históricas, como "fruto de práticas discursivas ou não, que os instituem, recortam-nos, nomeiam-nos, classificamnos, dão-nos a ver e a dizer”. Com base nesses pressupostos, este artigo apresentará análises de textos publicados em jornais e revistas brasileiros ${ }^{3}$, buscando abordar e problematizar alguns dos significados sobre a Amazônia que participam ativamente dos modos como essa região vem sendo inventada na contemporaneidade.

Embora a produção e a disseminação dos enunciados sobre a Amazônia venha ocorrendo, de modo entrelaçado, nos mais diversos espaços (como o meio acadêmico, o político, os movimentos sociais, entre outros), os textos da mídia impressa foram escolhidos principalmente em virtude

3 A pesquisa envolveu análise de textos publicados nos jornais Folha de São Paulo, O Estado de São Paulo, Valor Econômico e o Globo e nas revistas Bravo!, Veja e Istoé, entre os anos de 2007 e 2011. Como este artigo apresenta um recorte das análises desenvolvidas, não serão citados trechos de todos estes veículos impressos. 
da sua intensa circulação e do seu eficiente papel pedagógico. Nas últimas décadas, diversos autores, com destaque para aqueles que vêm promovendo conexões entre os Estudos Culturais com o campo da Educação, têm chamado a atenção para a função educativa exercida pela mídia.

Assim, como aponta Rocha (2004, p.128; 129):

\begin{abstract}
Muitos são os veículos de produção e reprodução de discursos na sociedade. Os de comunicação de massa ou (ditos) meios de comunicação social ou simplesmente "mídia" são os considerados de maior penetração e os que produzem e fazem circular mais rapidamente o maior número possível de informações. Por terem desenvolvido esta capacidade e habilidade de falarem com inúmeros indivíduos nas mais diferentes partes do planeta ao mesmo tempo, têm-se tornado constituidores de verdades e certezas, inventando, reforçando e multiplicando formas de viver e pensar o mundo.
\end{abstract}

Ao lerem jornais e revistas ou ao assistirem a programas televisivos, as pessoas aprendem a ver a Floresta Amazônica e seus habitantes de determinados modos, mesmo que nunca tenham estado, de fato, na Amazônia, como grande parte dos brasileiros. A esse respeito, Moreira (2003, p.1212) registra que, talvez, uma das maiores contribuições da mídia tenha sido a forma como transformou a nossa imagem de mundo, visto que, por meio dela, percebemos a realidade de povos e situações antes distantes no tempo e no espaço. Pode-se dizer, então, que a mídia, em seus diversos produtos, constrói, para milhões de brasileiros, maneiras específicas de se ver a Amazônia por meio das enunciações (e visibilidades) que a perpassam.

\title{
Ajustando o foco
}

As imagens da Floresta Amazônica se atualizam por meio de uma miríade de invençôes que se processam (ou se processaram) nas mais diversas instâncias, mas, por outro lado, não podemos esquecer que algumas invenções são consideradas mais "verdadeiras" que outras a partir de uma legitimação que se dá social e culturalmente. Guimarães (2006) ressalta que a construção discursiva dessa região ocorre a partir de relações de poder que são assimétricas, pois a floresta tem sido inscrita discursivamente a partir de determinados textos, sendo alguns mais influentes do que outros. Dentre os diversificados discursos sobre a Amazônia que coexistem na contemporaneidade, neste texto enfocaremos aqueles que se referem à articulação entre a floresta e as populações tradicionais que a habitam. Essa maneira de descrever inventar a Amazônia baseia-se na suposição de que as culturas tradicionais seriam mais puras e autênticas do que as culturas urbanas, por estarem mais intimamente ligadas à natureza. A importância que se atribui a essas populações é vinculada, sobretudo, ao seu reduzido impacto ambiental, pois se entende que elas são capazes 
de viver em ambientes naturais sem destruí-los, sendo capazes de garantir a continuidade dos recursos que utilizam por saberem como e quando utilizá-los. Registramos que esses discursos possuem uma expressiva aceitação no campo da educação ambiental e que a lição decorrente de tal abordagem, principalmente por meio de sua repercussão nas práticas em educação ambiental, é que deveríamos nos inspirar nos exemplos dados por esses povos para estabelecer relações mais próximas e respeitosas com a natureza.

Desse modo, os povos tradicionais amazônicos - também chamados de "povos da floresta" - se tornaram ícones do uso sustentável da Floresta Amazônica, representando uma alternativa às estratégias de desenvolvimento que, historicamente, predominaram na Amazônia. Leite (2001) sugere, inclusive, que o caboclo e o indígena deixaram de ser vistos como ameaças à floresta para assumirem - ao menos potencialmente - o papel de biozeladores. Como apontou Silva (1997), a construção da visão da floresta como uma reserva da biodiversidade mundial incluiu os grupos sociais subalternos basicamente como "espécimes" deste ambiente, devido ao fato de dependerem do extrativismo. Isso selou sua condição social de defensores da natureza e protetores das riquezas naturais, status tão polêmico quanto difícil de ser mantido (SILVA, 1997). Já o antropólogo Philippe Descola (1998) indica que a grande simpatia dedicada atualmente às populações tradicionais se deve a características que foram ostensivamente erigidas como seus atributos "naturais", como o respeito pela natureza, a atitude benévola para com as plantas e os animais e o cuidado de não pôr em perigo o equilíbrio dos ecossistemas. Seja como espécimes da floresta, seja como biozeladores, os discursos sobre os "povos da floresta" contribuem para a invenção de uma nova forma de concebermos e regularmos a região amazônica (e alguns de seus habitantes).

\section{Avatar é na Amazônia? Analogias entre populações tradicionais e alienígenas ecológicos (e azuis)}

A emergência do ambientalismo engendrou grandes transformações nos modos de pensar a Amazônia, produzindo novas invenções sobre este espaço em uma dimensão que ultrapassa (e muito) a esfera nacional. Portanto, desde a década de 1970, quando a agenda ambiental alcançou uma perspectiva global, a Amazônia tornou-se um dos principais temas do ativismo transnacional. Ou seja, essas novas significações que se entretecem à Amazônia a projetaram diretamente para um âmbito geopolítico global. Nesse processo de apropriação ambientalista da Amazônia, as populações tradicionais que habitam a região amazônica (com destaque para os povos indígenas), adquiriram o status de protetoras da natureza, sendo consideradas parceiras da causa ecológica. 
Um dos efeitos produtivos decorrentes de tais transformações diz respeito aos ganhos territoriais e à visibilidade internacional alcançada por estes povos, que passaram a ser considerados precursores de desejáveis modos de vida sustentáveis.

É interessante atentar para o fato de que a valorização das populações tradicionais no campo ambiental repousa, ainda, na prerrogativa de que o modo de vida rústico das populaçóes tradicionais deve ser mantido para que elas continuem exercendo seu papel na proteção dos recursos naturais. Acredita-se que, se tais populações forem "contaminadas" pelos nossos valores e nossos hábitos, provavelmente não serão mais capazes de realizar a função de zelar pelo ambiente onde vivem. De acordo com Kuper (2002, p.235), a imagem do indivíduo tradicional é construída para representar o "mundo ao qual, aparentemente, deveríamos desejar retornar - um mundo no qual o homem está em perfeita sintonia com a natureza”. Assim, a sedução exercida pela noção de populações tradicionais - mais ainda se estas adotarem a identidade de "povos da floresta" vincula-se ao desejo de que essas possam materializar uma forma sustentável de habitar o mundo, que se constituiria em uma alternativa ao modelo hegemônico de desenvolvimento. No excerto abaixo, Descola (2000, p.149) resume com clareza essa perspectiva:

Mais recente avatar da figura filosófica do bom selvagem, a Amazônia encarna, no presente, mais do que qualquer outra região do planeta, esta aguda nostalgia que o mundo industrializado sente de um modo de vida em que o equilíbrio entre o homem e a natureza seria harmoniosamente preservado.

Um exemplo bastante emblemático da penetração social do discurso sobre o bom selvagem ecológico pode ser encontrado no filme Avatar ${ }^{4}$, de 2009, que exibiu, com inovadora tecnologia 3D, a saga dos habitantes azuis de um hipotético Satélite Pandora, configurados como protótipos do "nativo ecológico", cuja função é defender a natureza de implacáveis (e devastadores) colonizadores terráqueos. Este filme, que obteve uma das maiores bilheterias da história do cinema até hoje, comoveu milhares de pessoas em todo o mundo através de um enredo que dá centralidade a discursos bastante assemelhados aos que estão sendo enfocados neste texto. A caracterização dos Na'vi (os habitantes de Pandora) remete a qualidades atribuídas às populações tradicionais, tais como um conhecimento profundo da natureza e uma visceral ligação com o território onde vivem.

\footnotetext{
4 Avatar é um filme norte-americano de ficção científica lançado em 2009. O filme foi escrito, dirigido e produzido por James Cameron. O seu enredo se localiza no ano de 2154 e é baseado em um conflito que se passa numa das luas do planeta Polyphemus, um dos três planetas gasosos fictícios que orbitam o sistema Alpha Centauri. Na trama, os colonizadores humanos e os nativos humanóides ( $\mathrm{Na}$ 'vi) combatem pelos recursos existentes no planeta. Em menos de um mês em cartaz, o filme superou um bilhão de dólares de faturamento e se tornou o primeiro filme a alcançar mais de dois bilhões de dólares em bilheteria.
} 
Os atributos dos seres humanos retratados no filme (com exceção daqueles que se sensibilizam e passam a lutar do lado dos aborígenes) também fazem referência ao modo como alguns discursos ambientalistas descrevem os seres humanos "brancos, ocidentais e civilizados": movidos pelo dinheiro e indiferentes às consequências de suas ações sobre a natureza.

Em decorrência do sucesso desse filme, não foram poucas as analogias feitas entre os alienígenas azuis da ficção hollywoodiana e os índios da Amazônia, de tal modo que muito se apontou que a caracterização dos Na’vi foi inspirada nos povos indígenas amazônicos. No período em que o filme foi lançado, circularam na mídia impressa diversos debates acerca das semelhanças entre a realidade dos povos amazônicos e os aborígenes do filme Avatar, o que foi potencializado com o engajamento do diretor do filme, em visita ao Brasil, nos protestos contra a implantação da Usina de Belo Monte, no Xingu. Na Figura 1, que reproduz uma matéria publicada na revista Bravo!, intitulada "Avatar é aqui" 5 , pode-se ver uma das abordagens relativas a essa aproximação.

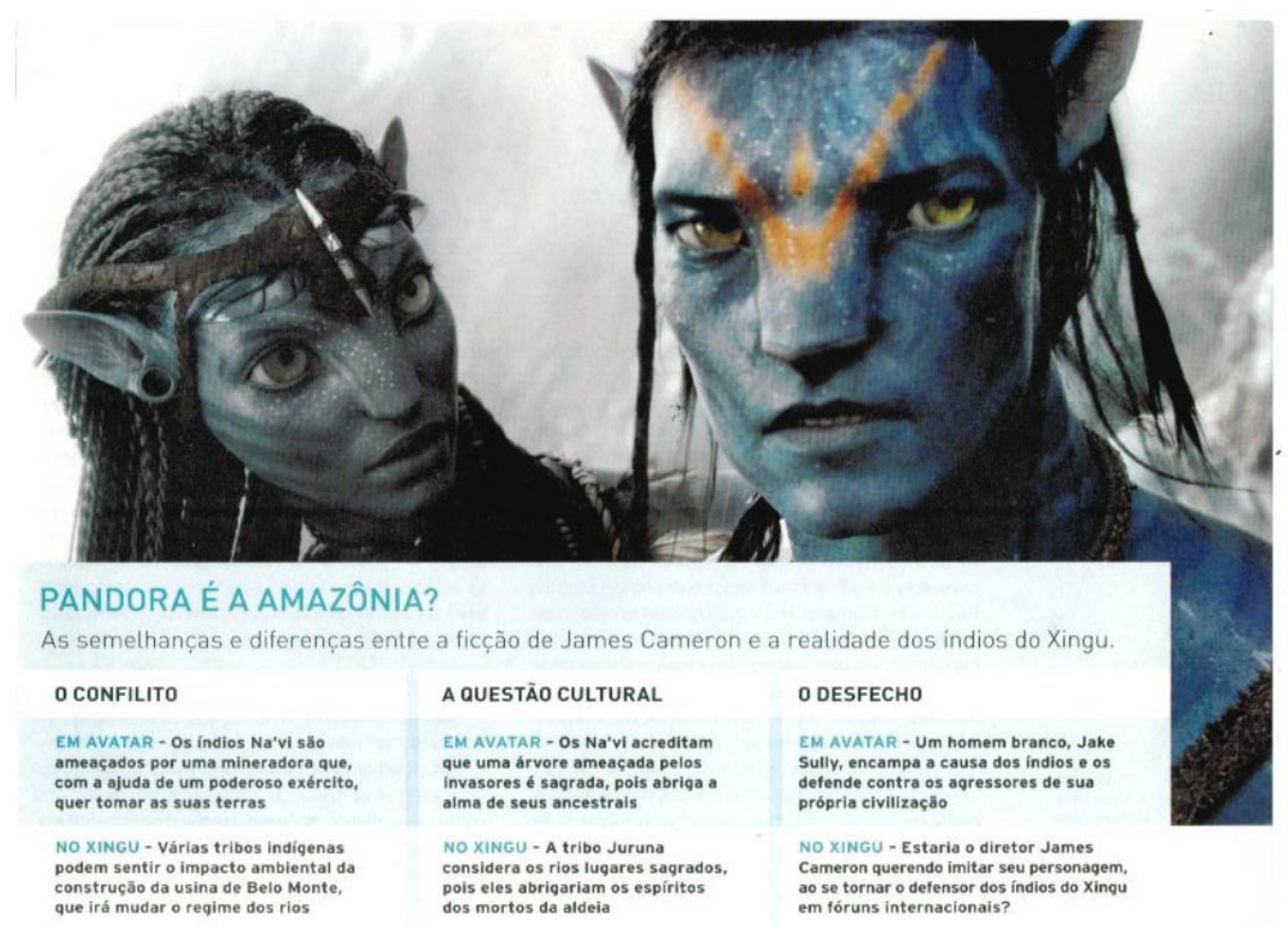

Figura 1: quadro sobre o filme Avatar apresentado na reportagem da revista Bravo!

5 Optamos por citar as referências dos textos analisados em notas de rodapé e não no final do texto, a fim de diferenciar textos que embasaram teoricamente o estudo dos textos que constituíram o corpus analítico do trabalho. Assim, os autores da matéria publicada na revista Bravo! de maio de 2010 (ano 12, no.153, p.52-56), são Anna Rachel Ferreira e Wagner Gorab. 
A pergunta "Pandora é a Amazônia?", seguida de uma comparação tão didaticamente estruturada entre os índios da ficção e os índios do Xingu, denota o quanto esta narrativa fílmica reforça a noção de "bom selvagem ecológico", tantas vezes associada aos povos indígenas e tradicionais que vivem na Amazônia. No estabelecimento de diferenças e semelhanças exposto no quadro estão realçados aspectos que se fazem presentes em muitos enunciados sobre as populações tradicionais, como: a opressão dos nativos pelas forças do capital; a idealização das culturas tradicionais - a coluna "a questão cultural" indica, por exemplo, que uma tribo da Amazônia considera que os rios são lugares sagrados da mesma forma como os "índios" do filme veneravam a árvore que mantinha o satélite Pandora em equilíbrio -; e, por fim, a identificação de alguns "não-índios" com as populações ameaçadas.

Buscando debater e problematizar alguns aspectos relativos a esta forma de descrever os índios, bem como as demais populações tradicionais amazônicas, apresentaremos alguns trechos de textos que empreenderam correlações entre o filme Avatar e a Amazônia. Gostaríamos de fazer a ressalva de que não temos, no entanto, o objetivo de realizar uma análise do filme Avatar, mas dar destaque a enunciados que foram por ele mobilizados. Como já mencionamos, vários textos teciam relações entre os habitantes de Pandora e os índios da Amazônia, tanto para criticar o "romantismo" que estaria presente nesta comparação, quanto para prestigiar o fato de o filme sensibilizar as pessoas com relação a este tema. Vejamos o excerto abaixo:

O filme se passa num planeta (Pandora) tipo Amazônia, onde existe uma enorme riqueza mineral escondida sob o solo coberto por uma floresta tropical cheia de "monstrinhos e plantas que acendem ao toque das mãos", habitada por uma população linda de seres que muito se parecem com índios americanos. [...] Os humanos gananciosos não são capazes de perceber como os Na’vi são seres em contato com a deusa cósmica. [...] O personagem humano principal é paraplégico, mas ao se tornar um Na’vi recupera as pernas: eis a metáfora da condição humana vista pelas lentes do romantismo degenerado. Somos uns aleijados em comparação aos belos índios místicos donos da verdade cósmica. E qual é essa verdade? Que a natureza é um grande cérebro pensante e que devemos nos dobrar a ela porque assim a vida será bela ${ }^{6}$.

No trecho apresentado, o colunista efetua uma crítica a clichês por ele encontrados na narrativa, sobretudo no que se refere às representações dos aborígenes em sua relação com a natureza do fictício satélite, mas que podem ser interpretadas como contendo alusões aos povos indígenas e à natureza do nosso planeta. Ao descrever sinteticamente o enredo do filme, o colunista não se

6 Folha de São Paulo, Caderno Ilustrada, 28/12/2009, “O romantismo idiota de Avatar”. O autor do texto é Luiz Felipe Pondé, filósofo e ensaísta brasileiro; possui uma coluna semanal no caderno Ilustrada deste jornal. 
furta a mencionar que o planeta mostrado na trama pode ser lido como a Amazônia, devido à imensa riqueza existente em meio a uma floresta tropical, da mesma forma que os seres alienígenas que o habitam "muito se parecem com os índios americanos". O autor salienta que os humanos do filme, cegos pela cobiça dos minerais que jazem sob a floresta, são insensíveis à umbilical e mística relação dos Na’vi com os elementos naturais. Por fim, o colunista lança mão de uma interessante análise acerca do modo como o filme caracteriza as diferentes formas de relação com a natureza apresentadas, respectivamente, por nós ("ocidentais”, "brancos”, “urbanos”) e pelos povos indígenas. Ele diz que, no filme, o protagonista humano que é paraplégico retoma a capacidade de caminhar ao se tornar um Nàvi, considerando que isso poderia ser pensado como uma metáfora para descrever a nossa condição de "aleijados", frente à incomparável sabedoria dos povos nativos sobre a natureza ("um grande cérebro pensante” que deveríamos reverenciar).

Analisando o conjunto dos aspectos abordados no excerto, é possível indicar que as críticas aos elementos que compõem o enredo do filme não se direcionam estritamente a tal produto cultural, mas aos discursos acionados por ele. Assim, pode-se dizer que esta narrativa fílmica se vale, de modo emblemático, dos discursos sobre o "bom selvagem ecológico", que muitas vezes impregnam as discussões sobre as populações tradicionais. Desse modo, argumentamos que tal produção cinematográfica encena a reprisada dicotomia moderna entre o selvagem puro e conectado com a natureza e o civilizado bélico e ambicioso, delineando um dualismo, no qual um dos elementos é mais forte e opressor do que o outro, narrado como frágil e ingênuo. Cabe reafirmar que discursos como esse projetam nos indígenas, tal como foi apontado por Viveiros de Castro (2005, p.124), "uma imagem do que perdemos ao deixar (imaginamos) na natureza para entrar (imaginamos) na história, enveredando pelo caminho sem volta da cultura e da civilização: urbanização, industrialização, poluição, superpopulação, globalização". E é nesse sentido que somos mais uma vez levados a idealizar a sintonia indígena com a natureza ao assumir ser essa inconsciente, orgânica e homeostática, tal como são caracterizados os aborígenes de Avatar.

No trecho apresentado, o colunista afirma ainda que, como se sugere no filme, "se tornar nativo", assumindo os elementos comumente atribuídos a uma "sabedoria ancestral indígena”, poderia ser a solução para a Humanidade. Porém, podemos cogitar que essa "solução" corresponderia à recusa de encarar o mundo em que efetivamente vivemos e as possibilidades de torná-lo melhor. Dessa forma, quando nos atemos à visão nostálgica dos povos tradicionais como vivendo uma vida exemplar em uma natureza igualmente exemplar, não nos implicamos com as coisas do nosso mundo, esquivando-nos de, como poeticamente diz Godoy (2008, p.128), nos envolvermos "no silêncio ruidoso por meio do qual nunca se para de inventar a vida”. 
Ademais, na narrativa de Avatar também se faz presente algo que poderíamos chamar de "consciência pesada" ou à "culpa" que os ocidentais carregariam tanto em relação aos povos indígenas - como os que foram dizimados nos processos de colonização - quanto no que tange a destruição da natureza. Essa culpa por haver criado o pior dos mundos, para usar novamente uma descrição de Godoy (2008), permeia muitos discursos ambientalistas, desde aqueles mais catastróficos, que preveem a vingança do planeta contra os seres humanos, até aqueles que propõem uma "reconexão" da cultura ocidental com a natureza como tentativa de conter a ruína. Segundo a autora:

A história que a ecologia narra é a história de uma ruína, por meio da qual advém uma proximidade da morte cada vez maior. Esta história é contada a partir da subsunção da vida e do pensamento à forma do verdadeiro, o que torna a ecologia o arauto das prescrições e das medidas profiláticas que nos permitirão viver (GODOY, 2008, p.102).

De certa maneira, a floresta amazônica encarnaria a oportunidade perfeita de expiar esta culpa, visto que ainda vivem por lá muitos povos indígenas (supostamente) “em comunhão" com a natureza, de modo semelhante ao que é retratado na ficção de Avatar. Logo, a comoção que a Amazônia suscita, nacionalmente e internacionalmente, pode estar vinculada também a esta necessidade de reparação dos males cometidos à natureza e aos "povos originais". Talvez até seja por esse motivo que esta obra de ficção foi associada, de forma recorrente, ao que "verdadeiramente" se passa em meio à selva amazônica. E esse paralelo ganhou mais força com a visita do diretor do filme, James Cameron, às comunidades indígenas do Xingu ameaçadas pela construção da usina de Belo Monte. Com a iminência da implantação desta hidrelétrica, que poderá trazer riscos para a continuidade dos modos de vida destes povos, parecem se reencenar os conflitos retratados no filme entre os civilizados e os selvagens. Para ampliar nossa argumentação, apresentamos dois excertos extraídos do jornal Folha de São Paulo que aludem a tal questão:

Para o cineasta James Cameron, o convite para ir à aldeia Mrotidjam, na terra indígena Trincheira Bacajá, foi um empurrão para credenciar seu mais novo filme, "Avatar", como uma obra de referência em engajamento ambiental, e não apenas uma alegoria tecnológica. A história do Xingu contra Belo Monte casou com o mundo fantástico de Pandora e vice-versa, um achado para Cameron. "Foi como encontrar o navio Titanic no fundo do mar." [[...] Cameron acha que o seu papel, como um "homem do futuro", como gosta de se definir, é evitar que aconteça no Brasil o mesmo que os Estados Unidos e seu povo indígena enfrentaram. ${ }^{7}$

7 Folha de São Paulo, Caderno Dinheiro, 18/04/2010, “Em 3D índios dizem que vão lutar contra Belo Monte”. 
No último dia do Fórum Internacional de Sustentabilidade, realizado em Manaus, o diretor do premiado filme "Avatar", James Cameron, "implorou” ao presidente Lula que reconsidere a intenção de construir a usina hidrelétrica de Belo Monte, no rio Xingu. O cineasta comparou a luta dos índios caiapós e ribeirinhos, que se opóem à usina, à dos Na’vi, povo criado por ele no filme e que vive na floresta de Pandora. [...] "O que temos aqui são povos ameaçados, como os Na'vi. Mas eles não têm pessoas aladas, como no filme".

Os fragmentos selecionados reportam-se ao já referido envolvimento do diretor de Avatar na mobilização contra a usina de Belo Monte e, ao mesmo tempo, tecem conexões entre os índios da Amazônia e os do filme. Essa combinação entre ficção hollywoodiana, enunciados sobre os "bons selvagens ecológicos" que viveriam na Amazônia e ao que se tem considerado ser um ativismo de celebridade, propiciou que os debates sobre a construção de Belo Monte e seus impactos sobre a população do Parque Indígena do Xingu alcançassem uma significativa atenção da mídia. Como se pode ver nos excertos, assim como no quadro da revista Bravo! apresentado anteriormente, não foram poucas as comparações entre os Na'vi de Avatar e os "povos da floresta amazônica”, nos quais tanto uns quanto outros figuram como vítimas de modelos de desenvolvimento predatórios e inconsequentes. Como o próprio Cameron afirmou num dos trechos apresentados, entrar em contato com os índios do Xingu afetados pela construção da hidrelétrica foi como "encontrar o Titanic no fundo do mar", aludindo a outro sucesso de bilheteria por ele dirigido.

Tal comparação também é explicitamente formulada no excerto seguinte, em que ele diz que os ribeirinhos e índios que serão afetados por Belo Monte são povos ameaçados pela ganância dos "brancos", assim como os aborígenes do seu filme, com a diferença de não serem os nativos da realidade “alados" como os Na’vi. Então, se a capacidade de voar foi apontada como a única diferença existente entre os índios da ficção e os da Amazônia, podemos supor estar Cameron afirmando que todas as outras características que os Na’vi apresentam no filme podem ser atribuídas aos povos tradicionais: a pureza, a ligação mística com os elementos da natureza, a sabedoria superior à dos "civilizados" , entre outras. Também vale ressaltar quanto a este excerto que, na impossibilidade de lutar contra os "invasores", tal como faz o protagonista humano do filme ao se juntar aos nativos, Cameron implorou ao presidente Lula que reconsiderasse a decisão de construir tal hidrelétrica.

8 Folha de São Paulo, $1{ }^{\circ}$ Caderno - Brasil, 28/03/2010, “Diretor de 'Avatar' pede que Brasil desista de hidrelétrica”.

9 Cabe lembrar que uma boa parte do filme é dedicada a retratar o árduo aprendizado do humano convertido em Na’vi a se relacionar com a natureza. 
Destacamos, também, o modo como o diretor julga que a sua obra de ficção pode "dar uma lição ao mundo", chegando, inclusive, a cogitar que seu ativismo pode contribuir para que não aconteça com o povo indígena do Brasil o mesmo que ocorreu com os indígenas norte-americanos. Assumindo o papel de "homem do futuro", ao se engajar na defesa da Floresta Amazônica e de seus habitantes indígenas, Cameron parece acreditar que o seu filme pode ser mais do que uma forma de entretenimento, por afetar as pessoas que o assistem, fazendo-as pensar sobre os temas tratados e, quiçá, promovendo transformações sociais. A esse respeito, em uma entrevista publicada na revista VEJA ${ }^{10}$, ele enuncia os seguintes questionamentos: "Os seres humanos serão capazes de absorver as ideias poderosas de Pandora e aplicá-las à própria vida, de maneira a recuperar tudo o que perderam? Em outras palavras, os Na’vi podem ter uma mensagem de esperança para nós, terráqueos?" De forma suficientemente clara, vemos o modo como realidade e ficção se encontram borradas nos discursos que articulam os índios do filme com os índios da Amazônia. Deveríamos, conforme postulam tais asserções, aprender com o filme e com os "povos primitivos" a respeitar todas as formas de vida, aplicando estas ideias nas nossas vidas para que possamos "recuperar tudo o que perdemos".

Embora possamos alegar que esta pretensão do diretor do filme seja um pouco exagerada, não há como negar o impacto deste produto cinematográfico em termos de audiência, bem como não devemos menosprezar as marcas e aprendizados que se processam quando assistimos a um filme, lemos um livro, escutamos uma música. E, principalmente, quando tal filme, livro ou música fazem reverberar enunciados que nos são familiares por se articularem a discursos que possuem uma significativa penetração social. Por conseguinte, podemos admitir que os discursos sobre os "bons selvagens ecológicos" exercem efeitos subjetivadores não apenas nas populações tradicionais, mas também nos demais sujeitos acessados por tais discursos.

Nesse sentido, acreditamos ser fundamental problematizar sistematicamente as lições relativas às populações tradicionais amazônicas e a sua conexão profunda com a natureza, que podemos aprender com discursos que circulam nas mais diversas instâncias sociais (como, por exemplo, no filme Avatar). Isso porque tais discursos produzem uma determinada forma de lidar com as populações consideradas tradicionais, tanto no que se refere aos modos de imaginá-las por meio de estereótipos do "bom selvagem", quanto a partir de ações destinadas a conduzir a conduta - para usar uma expressão foucaultiana - dessas comunidades por meio de políticas públicas, projetos e programas conduzidos por instituições variadas. Se, de acordo com grande parte dos

10 VEJA, Edição 2160 /ano 43 - n.15, 14/04/2010, “O visionário de Avatar”, entrevista com James Cameron. 
enunciados que caracterizam os grupos tradicionais, esses mantêm relações harmoniosas com o meio devido a sua posição marginal com relação ao mercado e ao modo de vida ocidental, como tais discursos reagem à inserção destes grupos no mundo globalizado? O que dizer das populações tradicionais que não fazem uso racional dos recursos naturais? Como lidar com populações tradicionais que não se encaixam nos requisitos desta definição? Além disso, caberia também levantar uma questão crucial: e as comunidades cujas atitudes são configuradas como predatórias ou destrutivas perderiam o direito de serem consideradas populações tradicionais?

É interessante registrar que, quando a mídia divulga fatos que desestabilizam a imagem idealizada que se tem das populações tradicionais, as reações da opinião pública são exacerbadas: o índio que colabora com o madeireiro é descrito de forma impiedosa, sendo o motivo principal invocado para tanto o de que ele estaria "indo contra a sua própria natureza" ${ }^{11}$. Alguns exemplos deste tipo de "regulação" exercido sobre as populações tradicionais são fornecidos por Bonin (2007), quando ela relata que notícias de povos indígenas que participam de ações de degradação ambiental provocam estranhamento, assim como a presença indígena nos centros urbanos. Como a autora ressalta, os discursos que condicionam as ações dos índios à preservação da natureza pressupõem uma essência indígena, produzindo "um sentido de permanência e fixidez: como se esses fossem ‘sempre os mesmos'” (p.146).

Contudo, por outro lado, não podemos desconsiderar os ganhos obtidos pelas populações tradicionais ao se atrelarem aos movimentos ambientalistas, assumindo "identidades ecológicas". Como salienta Ulloa (2003), alguns destes benefícios são a criação de novas arenas de negociação, a obtenção de recursos e, até mesmo, o empoderamento dessas comunidades, por meio da consolidação de direitos, principalmente em relação territórios. Na mesma direção, Miraglia (2007) considera que, se os chamados "povos da floresta" foram cooptados pela retórica ambientalista, assumindo o papel de "ecologistas natos", eles também se apropriaram dessas retóricas nas negociações políticas em favor de seus interesses. Por sua vez, Little (2004, p.336; 337) afirma que "os povos tradicionais não são mais simples receptores passivos das intervenções ambientalistas, já que internalizaram e reelaboram essas influências em função

11 Nesse sentido, é bem conhecido o caso dos índios kayapó que, como relata Miraglia (2007), tornaram-se célebres na mídia pela intensa mobilização quanto à demarcação das suas terras, sendo apresentados como bons selvagens e defensores da floresta amazônica (por exemplo, o cacique Raoni). Logo depois, a mesma mídia rotulou-os de "índios mercantilistas", em decorrência de seu envolvimento com o garimpo e a extração madeireira. A autora analisa que "tal fato ocorreu com os Kayapós, como descrito, quando estes fizeram opções próprias de consumo e de uso dos recursos naturais do seu território que não correspondiam do mesmo modo às expectativas da representação tradicional do 'indígena ecologista natural' aclamada por parte do movimento ambientalista” (ibid. p.126). 
de suas próprias cosmologias e finalidades políticas". Dessa forma, visando à conquista de direitos, os grupos sociais que "vestem a camisa" de populações tradicionais assumem e se valem dos discursos ambientalistas, alegando a sua relação amigável e respeitosa com a natureza.

No entanto, caberia perguntar: desempenhar o papel de guardião da floresta não seria um fardo muito pesado para se carregar a longo prazo? Como assinalou Miraglia (2007, p.129), “a justificativa do 'comportamento ambientalista indígena' pode ser, ao mesmo tempo, um argumento politicamente rentável para estes povos, como também, em determinadas conjunturas, pode se reverter em uma armadilha política para os mesmos”. No limite, as populações tradicionais podem ficar aprisionadas à imagem idealizada do "bom selvagem”, tendo suas possibilidades de existência restritas a esse estereótipo. Mas é preciso considerar a possibilidade de as condições em que vivem os povos tradicionais da Amazônia não serem exatamente as mesmas retratadas no filme Avatar, ainda que, para muitos, seja bastante reconfortante imaginar os "povos da floresta" como seres idílicos, belos e puros.

\section{Verdades sobre eles, lições para nós}

A partir da discussão esboçada neste estudo, buscamos abordar discursos que promovem articulações entre a floresta amazônica e as populações tradicionais que a habitam, mostrando que estes circulam não apenas na esfera acadêmica ou no âmbito da militância ecológica, mas atravessam as mais diversas instâncias da cultura, como aquelas que convencionalmente são chamadas de "cultura de massa", operando como pedagogias culturais. Consideramos que a ação subjetivadora de enunciados - tais como os que são postos em circulação pelo filme Avatar não se dirige apenas às populações tradicionais, mas a todos os indivíduos que são acessados por eles nas mais diferentes instâncias socioculturais: seja como um modelo para as nossas ações; seja para lamentar o modo como nós, "brancos", destruímos a natureza; seja para inspirar práticas sustentáveis. Somos, muitas vezes, levados a pensar nos povos tradicionais como o nosso "avesso", como aquilo que poderíamos ter sido se não tivéssemos nos "desvirtuado". Como comenta Godoy (2008, p.112), somos subjetivados atualmente por uma "moral ecológica”, que produz um homem que "carrega nas costas todos os animais e o próprio homem, expiando a culpar de haver gerado o pior dos mundos”. E essa culpa ecológica nutre o imaginário sobre o bom selvagem, por meio do qual é idealizada a relação entre as populações ditas tradicionais e a natureza, gerando, então, a necessidade de preservar e proteger essas culturas da mesma forma que se postula ser necessário conservar a natureza: mantendo-as intactas. 
Dessa forma, a vinculação entre populações tradicionais e floresta amazônica engendra um recíproco processo de constituição, uma vez que tanto os significados sobre essas populações participam dos modos de "inventar" a Amazônia na contemporaneidade, quanto a floresta é descrita como um espaço considerado mais adequado para a manutenção dos estilos de vida das comunidades tidas como tradicionais. Ainda que a definição de populações tradicionais dê margem a algumas controvérsias e imprecisões, ela vem conquistando uma grande popularidade em variados âmbitos e, sobretudo, tem se tornado um importante meio para que muitas comunidades consigam acessar determinados direitos, ligados ao uso da terra e dos recursos naturais. Por isso, para que possam obter tais benefícios, muitos povos têm assumido essa identidade.

Entretanto, tornar-se população tradicional não traz apenas vantagens. Aderir a esta categoria equivale a ter que corresponder a uma série de características que se espera que estas comunidades apresentem (e.g. modos de vidas rústicos, relações respeitosas com a natureza, conhecimento profundo dos ciclos naturais, baixa inserção na lógica econômica ocidental), algo que nem sempre é fácil de ser sustentado nestes tempos globalizados. Em síntese, podemos dizer que as populações tradicionais são subjetivadas (e enredadas) pelos discursos do “bom selvagem ecológico", uma vez que aderem voluntariamente a esta categoria, ficando, assim, comprometidas com os enunciados que as descrevem como protetoras da natureza. Como aponta Viveiros de Castro (2005, p.126), os povos indígenas (e, de modo geral, as populações tradicionais) são valorizados por se constituírem como um reservatório de tecnologias úteis para o desenvolvimento sustentável da Amazônia, o que não deixa de ser uma visão utilitarista, "que parece só admitir o direito à existência dos outros se estes servirem a algo para nós".

Enfim,cabedizerque talvezo processo de descreverosenunciadosque atribuem sentidosà articulação entre populações tradicionais e Amazônia mostre que a produtividade destas coisas ditas não se deva exatamente a essa articulação em si, mas a sua participação na constituição de determinadas verdades ambientais vigentes nos tempos atuais. Algumas das verdades ambientais contemporâneas que destacamos nas discussões conduzidas neste artigo dizem respeito à instituição de modos mais sustentáveis de lidar com os recursos naturais e de tecer relações com a biodiversidade amazônica que seriam característicos das populações tradicionais. Como afirma Fischer (2003, p.373), o estudo de enunciados pode conduzir à apreensão de acontecimentos que se passam no interior de uma formação discursiva: "esse feixe de relações que 'faz' com que certas coisas possam ser ditas (e serem recebidas como verdadeiras), num certo momento e lugar”. Desse modo, esmiuçar os enunciados que dizem coisas sobre as populações tradicionais, bem como sobre as formas consideradas mais 
corretas de intervir na floresta amazônica, pode contribuir para que se apreendam aspectos importantes acerca dos modos como os discursos ambientalistas participam na regulação das formas como entendemos e nos relacionamos com a natureza e entre nós mesmos, seres humanos.

\section{REFERENCIAS}

ALBUQUERQUE JUNIOR, Durval M. História: a arte de inventar o passado. Bauru: EDUSC, 2007.

BONIN, Iara. E por falar em povos indígenas... Quais narrativas contam em práticas pedagógicas. Tese (doutorado). Programa de Pós-graduação em Educação, UFRGS, Porto Alegre, 2007.

BRASIL. Presidência da República. Decreto n. 6.040, de 7 de fevereiro de 2007. Institui a Política Nacional de Desenvolvimento Sustentável dos Povos e Comunidades Tradicionais.

DESCOLA, Philippe. Ecologia e cosmologia. In: DIEGUES, Antonio Carlos (org.). Etnoconservação: novos rumos para a proteção da natureza nos trópicos. São Paulo: Hucitec; Nupaub-USP; Annablume, 2000.

. Estrutura ou sentimento: a relação com o animal na Amazônia. Mana, Rio de Janeiro, v.4, n.1, p. 23-45, 1998.

FISCHER, Rosa M.B. Foucault revoluciona a pesquisa em educação? Perspectiva, Florianópolis, v.21, n.2, p.371-389, jul./dez., 2003.

GODOY, Ana. A menor das ecologias. São Paulo: Editora da Universidade de São Paulo, 2008.

GUIMARÃES, Leandro B. Um olhar nacional sobre a Amazônia: apreendendo a floresta em textos de Euclides da Cunha. Tese (doutorado). Programa de Pós-Graduação em Educação, UFRGS, Porto Alegre, 2006.

KUPER, Adam. O retorno do nativo. Horizontes Antropológicos, Porto Alegre, ano 8, n.17, p.213-237, jun. 2002.

LEITE, Marcelo. A floresta amazônica. São Paulo: Publifolha, 2001. 
LITTLE, Paul E. Ambientalismo e Amazônia: encontros e desencontros. In: TOURRAND, Jean-François; BURSZTYB, Marcel (orgs.). Amazônia: cenas e cenários. Brasília: Universidade de Brasília, 2004.

MIRAGLIA, Ana Beatriz. "Desenvolvimento”, “meio ambiente” e "cultura”. Notas críticas sobre o debate socioambiental indigenista amazônico. Dissertação (mestrado). Programa de PósGraduação em Antropologia Social, USP, São Paulo, 2007.

MOREIRA, Alberto S. Cultura midiática e educação infantil. Educação e Sociedade, Campinas, v.24, n.85, p.1203-1235, dez. 2003.

ROCHA, Cristianne F. O espaço escolar em revista. In: COSTA, Marisa V. (org.). Estudos culturais em educação: mídia, arquitetura, brinquedo, biologia, literatura, cinema... Porto Alegre: Ed. Universidade/UFRGS, 2004.

SILVA, Marilene Corrêa da. Metamorfoses da Amazônia. Tese (doutorado). Departamento de Ciências Sociais do Instituto de Filosofia e Ciências Humanas, UNICAMP, Campinas, 1997.

ULLOA Astrid The Ecological Native: Indigenous Peoples' Movements and Eco-governmentality in Colombia. In: Meeting of the Latin American Studies Association, 2003, Dallas, Texas. Proceedings... Texas, 2003. Extraído de: lasa.international.pitt.edu/Lasa2003/UlloaAstrid.pdf, em 22/08/2008.

VIVEIROS DE CASTRO, Eduardo. O perspectivismo ameríndio ou a natureza em pessoa. Ciência \& Ambiente, Santa Maria, n.31, jul/dez, 2005. p.122-132. 